\title{
Personal, Psychological Situational and Communicational Profile of the Gram Cultivators in Hamirpur District of UttarPradesh, India
}

\author{
Vikas Bajpai* and Anindita Saha \\ Department of Agricultural Extension, Institute of Agriculture, (PSB) Sriniketan, \\ Visva-Bharati University, Bolpur - 731236 \\ *Corresponding author
}

\begin{tabular}{l} 
K e y w o r d s \\
gram cultivators, \\
$\begin{array}{l}\text { Socio-personal, } \\
\text { communication, } \\
\text { psychological }\end{array}$ \\
\hline Article Info \\
\hline $\begin{array}{l}\text { Accepted: } \\
\text { 15 February } 2020 \\
\text { Available Online: } \\
\text { 10 March } 2020\end{array}$ \\
\hline
\end{tabular}

\section{A B S T R A C T}

The study conducted in Hamirpur district of Uttar-Pradesh. The investigation was carried out Personal, psychological situational and communicational profile of the gram cultivators. The findings revealed that nearly $(66 \%)$ percentage of gram cultivators belonged to middle age and $(33.3 \%)$ percentage of gram cultivators belonged to old age category. Majority of gram cultivators were in medium educational level in general and same trend was found in all the three categories. The average land holdings of small, medium and big gram cultivators were 21,31 , and more than 58 acres, respectively. The land holdings of gram cultivators ranged between 15 - 113 acres. The average income of small gram holders is about Rs.1.00 lakh, while large land holders it is around Rs.5.00 lakhs. Majority had medium farming experience and equal per cent of gram cultivators had low and high gram farming experience. Majority (51\%) had low level of mass media participation and 39 per cent had medium and only 10 per cent had high level of mass media participation. 46.50 per cent of gram cultivators followed by high and medium level of organizational participation almost equal per cent of farmers belonged to high $(36.00 \%)$ and low (35.00\%) level of extension contact while 29 per cent to medium level of extension contact. Thirty-nine percentages of farmers had high extension participation followed by medium (36\%) and low (24.50\%) extension participation and 44.50 of gram cultivators were found in medium level of scientific orientation. 50 per cent of big gram cultivators possessed low achievement motivation and nearly equal percentage of medium and small gram cultivators belonged to medium to high level of achievement motivation. In case of big cultivators 35 per cent had high level of achievement motivation.

\section{Introduction}

India has achieved self-sufficiency in food grain production and now the major concern is to achieve higher growth rate. The focus has now shifted to GRAM (pulse crop) which besides imparting nutritional security, offers a great potential for efficient input use, higher returns per unit area, crops diversification, foreign exchange earnings and greater 
employment generation through post-harvest processing in agro-industries. Continuous focused attention and higher investment in agronomy during the last decade has paid rich dividends in terms of increased production, quality and productivity of agronomy crops with manifold export potential. GRAMs crops occupy 8.5 per cent of gross cropped area of the country with a total production of 210 million tones. GRAM contributes 11 per cent in GDP of agriculture and 19.50 per cent in earnings of the agriculture.

The total export of agronomy produce was Rs. 67592.82 million in 2007-08. There has been a significant increase in area and production of crops particularly in Andhra Pradesh, Uttar Pradesh Madhya Pradesh, Tamil Nadu, Maharashtra, Rajasthan, Punjab, Haryana and Uttaranchal. This growth assumes more significance as agriculture sector has been able to achieve only less than 2 per cent growth during the $12^{\text {th }}$ five year plan. At present, India is the third largest producer of GRAM (49.5 million tons) and cereals crops (146 million tons) in the world contributing 10.23 and 14.45 per cent to the total world production of GRAM and cereals, respectively. The international trade in terms of agronomy produce has increased fivefold between 1961 to 2001, from 24 million tons to 129 million tons.

The government of India has taken agronomy as a key development area and it is evident from the increased financial outlays in the $9^{\text {th }}$ and $10^{\text {th }}$ five years plans. The main objective of the TMOP'S is to double the GRAM production from 60 million tons to 300 million tons by 2011-12.

The TMOP'S was launched in the year 198990 with a total budget of Rs. 6500 cores. The scheme is fully funded by the Central Government and the scheme was launched initially with an allocation of Rs. 630 corers.
The Central Government has provided Rs. 1,000 corers under the TMOP'S for 2006-07 so that area and production technology could be upgraded in GRAM. TMOP'S seeks to contribute immensely in the second green revolution. Diversification and value addition are the key words in Indian agriculture in the $21^{\text {st }}$ century. Our country has varied agroclimates which gives us a competitive edge in production, made for export over an extended period. In different agro climates of the country, different crops, GRAM and oilseed crops are being grown to cater to the domestic as well as global demands. Value addition is a key word in the development of agronomy as this can provide a lot employment opportunity in the rural areas and thus strengthening the agriculture sector.

Gram is one of the most important GRAM crops of dry arid zone which has acclimatized to arid and semi-arid agro climatic conditions prevailing in Indian sub-continent. Due to the adaptability of this crop to varied agroclimatic conditions, the scope of expansion of area in the Deccan plateau region is very large. The area under gram cultivation has been increasing steadily with the introduction of new technologies in its cultivation and post-harvest management. Thus, India is emerging as one of the most important gram (pulse) growing countries in the world. Gram is currently grown in three distinct regions in India namely

Tropical region comprises hot tropical areas like Western Maharashtra (Nasik, Solapur, Sangli, Pune, Satara and Osmanabad districts), Uttar Pradesh (Jhanshi, Banda, Hamirpur and Mahoba districts), Telenagana (Hyderabad, Rangareddy, Mahbubnagar and Medak districts) and Madhya Pradesh (Satna, Datia, Bhind and Balaghat districts). Gram is an important commercial GRAM crop of India. The world production of grams is presently 43 percent, out of which accounts 
for 1.2 million tons of grams making a share of 1.83 per cent of the world production and 3 per cent of the total fruit production in the country.

The area under this crop has increased by 50 per cent of the production by 71 per cent in the country in the last decade (1994-2004) due to the economic importance of this crop. Its economic significance is due to good backup of gram industry in terms of backward and forward linkages that offers employment to a large number of skilled and unskilled people on the farm, trade and service.

India has achieved the highest productivity of $09 \mathrm{t} / \mathrm{ha}$ in the production of table grams. Presently in India about 85 per cent of gram is used for dal purpose, nearly 15 per cent is dried for raisin production.

Though this crop is processed to the largest extent compared to other GRAM in the country, the processing of this crop in our country is very less than to the traditional gram growing countries in the world, where more than 85 per cent of the produce is processed in the form of dal. etc. however, the processed products viz., satu, raisins and gram sweets are the most popular products from grams all over the world.

It is on record that Rani Laxmi Bai, the ruler of Jhanshi (Comprising Southern Parts of Uttar Pradesh), introduced several gram varieties in Maurnipur, which was her royal retreat during 1780's. She imported several varieties of grams through M/s. E. H. Butcher, T. T. Leonard in 1885 . These varieties were first introduced and later on given to the farmers around Uttar Pradesh for their commercial cultivation. The introduction of white gram (Cicer arietinum L.) took place in the late fifties, under the aegis of the Department of agriculture, and the early varieties cultivated then were Avrodhi,
Gaurav, K-850, K-4 and Radhey. A little later, the other varieties such as KP-75, Pusa372etc., were introduced.

The pioneers responsible for spreading and popularization of gram cultivation (during the sixties) were Dr. M. H. Marigowda, the then Director of agriculture, Sri. S.D. Yadav, Professor of agronomy college of Agriculture, Kanpur. There were as many as 180 varieties of grams collected and grown at the crop farm of IIPR as demonstration plot. The Department of Agriculture did a yeoman service in terms of providing plants, technical advice and marketing services

\section{Materials and Methods}

The expost-facto research design was used for the study. This design was considered appropriate because, the phenomena had already occurred. Cooper and Schindler (1999) defined expost-facto as a research design in which investigations have no control over the variables in the sense of being able to manipulate them. They can only report what has happened or what is happening.

The study was conducted in Hamirpur district of Uttar Pradesh state as these stood first area and production of gram in Uttar Pradesh. Gram is one of the important GRAM crops of Uttar Pradesh with an area of 6534 ha and annual production of more than two lakh tones (NBH, 2003-4). The soil, water and weather conditions in the state vary from one part to other. Taking this aspect into consideration the area under gram cultivation is broadly classified as western zone. In western zone, Hamirpur districts are the major areas where in gram is cultivated under large area. Hamirpur stands first area and production. Hence, it was decided to conduct the study in Hamirpur district of Uttar Pradesh. 


\section{Results and Discussion}

\section{Profile of the gram cultivators}

The data presented in Table-1 A,B and c gives a detailed account of personal psychological situational and communicational profile of the gram cultivators.

\section{Personal profile}

\section{Age}

It could be seen from the Table that 42.50 per cent of the farmers belonged to old age category followed by middle age (39\%) and young age $(18.50 \%)$. Among three categories of farmers , 50.96 per cent of medium farmers belonged to middle age category followed by big $(40 \%)$ and only 16.07 per cent to small farmers' category, while, equal percent (30\%) of big farmers fell under young age group and 39.29 per cent to old age. None of the medium farmers belonged to young age category.

\section{Education}

The data with respect to educational level of respondents showed that 43.50 per cent of the farmers belonged to low educational level followed by higher educational level $(35 \%)$ and medium (21.50\%) educational level. Among different categories of farmers, 46.15 per cent of medium farmers belonged to low educational status followed by small $(42.86 \%)$ and big $(37.50 \%)$ farmers. Further, 35 per cent of big, 39.42 and 26.79 per cent of medium and small farmers belonged to higher educational level, respectively.

\section{Land holding}

Overall, 39.50 per cent of gram cultivators belonged to small land holdings category ( 21 acre) followed by 31 per cent to medium (2128 acre) and 24.50 per cent to big land holdings ( $>58$ acre).

Among different categories of gram cultivators, 47.50 per cent of big (up to 50 acre) and equal (37.50\%) percentage of small (up to 15 acre) and medium (up to 26 acre) gram cultivators belonged to low land holdings category followed by 35.71 per cent of small (15.27 acre), 35 per cent of big (50113 acre) and 30.77 per cent of medium (2641 acre) gram cultivators who belonged to medium land holdings category, whereas, 31.73 per cent of medium ( $>41$ acre) followed by 26.78 per cent of small ( $>27$ acre) and 17.50 per cent of big (>113 acre) gram cultivators belonged to high land holding category.

\section{Annual income}

The data with respect to annual income revealed from Table-1 that, overall 36 per cent of gram cultivators belonged to medium income category followed by 33 per cent low and 31 per cent who belonged to high income category.

Among the three categories, 42.50 per cent big land holders belonged to low income (up to Rs. 3,65,623) group, followed by 40 per cent to medium (Rs. 3,66,000-7,25,000) and 17.50 per cent to high income $(>7,25,000)$ category.

Further, medium land holders $(39.42 \%)$ of gram cultivators belonged to medium (Rs. $1,95,000-2,65,000)$ income category followed by 32.69 per cent to high income (>Rs. $2,65,000$ ) and 27.88 per cent belonged to low income (up to Rs. 1,95,000) category, while 37.50 per cent of small farmers with high income (>Rs. $1,41,000)$ followed by 35.71 per cent low income (up to Rs. 98,000) and 26.79 per cent of small land holders belonged to medium income category (Rs. 98,0001,40,000). 


\section{Farming experience}

The data pertaining to farming experience of gram showed that 39.50 per cent of the farmers had medium (15-22 years) experience followed by low (31\%) and high $(29.50 \%)$ gram growing experience. Among the three categories, 51.92 per cent of medium, 50 per cent of small and 42.50 per cent of big farmers had medium, low and high gram farming experience respectively.

\section{Communication attributes}

\section{Mass media participation}

It was observed from table-1 that the majority (51\%) had low mass media participation and 39 per cent had high only and only 10 per cent had medium level of mass media participation. Mass media participation with respect to different categories of farmers was such that majority of medium $(59.62 \%)$ and big $(55 \%)$ had low mass media participation while, high mass media participation was observed among 45.00 per cent of big and 40.38 per cent of medium gram cultivators.

\section{Organizational participation}

Low level of organizational participation was observed with 46.50 per cent of gram cultivators followed by high and medium level of participation. Further, among different categories, 50 per cent of small followed by medium (49.04\%) and big (35\%) farmers had low level of organizational participation while, 42.50 per cent of big farmers had medium level of organizational participation. In other category not much variation was observed.

\section{Extension contact}

Almost equal per cent of farmers belonged to high $(36 \%)$ and low (35\%) level of extension contact while 29 per cent to medium level of extension contact. Further, among three categories of land holders, 48.21 per cent of small farmers had high extension contact and big $(47.50 \%)$ had low level of extension contact and nearly equal per cent of small $(21.43 \%)$ and big (20\%) had medium level of extension contact. There was not much variation in case of medium category farmers.

\section{Extension participation}

From Table-1 it is clear that 39.50 per cent of farmers had high extension participation followed by medium (36\%) and low (24.50\%) extension participation. Among the different categories of farmers, nearly equal percent of medium (50\%) and small (48.21\%) farmers belonged to high and low extension participation respectively, whereas there was not much variation among big farmers.

\section{Psychological attributes}

\section{Scientific orientation}

The data pertaining to scientific orientation in table-1 clearly indicated that 44.50 per cent of farmers belonged to medium level of scientific orientation followed by high (38.50\%) and low (17\%) level of scientific orientation. Further, among different category of farmers, half $(50 \%)$ of the medium followed by small land holders $(42.86 \%)$ belonged to medium level of scientific orientation. About 47.00 per cent of medium and 25 per cent of small farmers had high level of scientific orientation, while not much variation was observed among big farmers.

\section{Personal attributes}

Age

It can be observed from table-1 that nearly equal percentage of gram cultivators belonged 
to old age and middle age category and among different categories of gram cultivators belonged to middle age and old age, while in case of small gram cultivators' majority were young and of old age.

Gram being an important commercial GRAM crop in Hamirpur district introduced in late seventies has gained importance during last 15 years. As result many gram cultivators are found cultivating gram in this districts, so majority were found in middle and old age category. Due to high economic returns, small gram cultivators were also motivated, and established gram farms in small areas during the recent past, hence majority of small gram cultivators belonged to young age category. The findings were in conformity with the findings reported by Srinivas Reddy (1995) and Sarvanakumar (1996).

\section{Education}

Majority of gram cultivators were in low educational level in general and same trend was found in all the three categories of gram cultivators. One third of the gram cultivators were in high education category and there was not much variation among big gram cultivators with respect to educational level.

The Hamirpur districts' literacy rate is low in general. The probable reason for lower educational level is that majority of the small and medium gram cultivators were attracted towards gram cultivation, limiting them to further their education. This resulted in low educational level.

The result was in line with the findings of Ajay kumar (1989) who reported in his study on gram cultivators that $27 \%$ of the respondents had education upto college level, $38 \%$ of the respondents studied up to graduation and none of the respondents were found to be illiterate. Similar findings were reported by Sarvanakumar (1996) and Birajdar (1999).

\section{Land holding}

It may be noted that the average land holdings of small, medium and big gram cultivators was 21,33 and 58 acres, respectively. So it means as such majority of gram cultivators are big farmers. The size of the farms varied due to their varied investment capacity and interest. However, the results indicated that big farmers were able to own big grams farms than the medium and big. The results also indicated that the size of the land holdings of gram cultivators ranged between 15-113 acres. The findings were in conformity with the findings of Ajaykumar (1989), Saravanakumar (1996) and Birajdar (1999).

\section{Annual income}

The results once again proved that gram is richman's crop. The average income small gram holders is about Rs. 1 lakh, while large land holders it is around 2.5 lakhs. The income levels are in proportion to the total land holding owned by the farmer and also the area under gram. It may be noted that the average gross income of gram is around ten thousand rupees per acre. Shashidhara (2003) in his study on socio economic profile of drip irrigation farmers in Shimoga and Davanagere district of Karnataka state revealed that, comparatively more number of farmers (46.67\%) belonged to semi medium category followed by medium (32.22\%) and small land holdings categories $(18.89 \%)$. The result of the study were in line with findings of Chandran (1997) and Angadi (1999).

\section{Farming experience}

The data with respect to gram farming experience showed that majority had medium farming experience and equal per cent of 
gram cultivators had low and high gram farming experience. However, not much variation was observed within the three categories of gram cultivators.

Gram farming experience mainly depends upon age of the farmer. A majority of medium and big gram cultivators belonged to middle age and old age category and they might have started gram farming in their early age itself. So they had more gram farming experience as compared to small gram cultivators.

\section{Communication attributes}

\section{Mass Media Participation}

A majority of gram cultivators belonged to low and high mass media participation categories and less per cent of gram cultivators belonged to medium category. However among three categories of gram cultivators equal percentage of big and medium category gram cultivators had relatively high mass media participation and in case of small gram cultivators no variation was found with respect to mass media participation.

It was observed that the majority of medium and big gram cultivators utilized mass media like radio, TV, newspaper and magazines. It might be due to better educational level and easy access to various mass media. Low mass media use might be due to lack of interest and belief in the information from mass media, further their rich experience in gram cultivation might have restricted the use of mass media.

The results were in contraints with the results of Kumbar (1983) who reported in his study on gram in Bijapur district reported that 51.70 per cent of gram cultivators had high level of mass media participation and 48.30 per cent of the farmers had low level of mass media participation. The results were in conformity with the findings of Reddy (1995).

\section{Organizational participation}

The results presented in table 1 revealed that majority of gram cultivators had low organizational participation and among small, medium and big gram cultivators half the number of small and medium gram cultivators had low organizational participation and big gram cultivators had medium organizational participation. There was not much variation in distribution of respondents in high organizational participation category among different categories of gram cultivators. The reason for low organizational participation might be due to the fact that gram cultivation involves intensive care and operations, so majority of cultivators did not find time to involve themselves in organizational activities. Gram cultivators associations are one which majority of gram cultivators becomes members that is why; considerable percentage of all categories of gram cultivators had high organizational participation and other local institutions.

Similar findings were reported by Meeran and prince (1999) in his s6tudy he found that 78 per cent of the respondents were found to have low level of organizational participation. Agricultural Credit Societies, Local Shrimp Farmers Association and Caste Association were the some of important organizations in which the respondents participated. The findings were in conformity with the results reported by Gowda (2002).

\section{Extension contact}

About 35 percentages of gram cultivators belonged to low, medium and high extension contact, while majority of gram cultivators had low to medium extension contact. Due to high technology nature of gram crop majority 
of big gram cultivators had contacted with premium research stations for gram and had comparatively less extension contact with local available sources for technical information. Their contact with line department and other institutes was mostly for subsidy purpose. Small gram cultivators due to their limited exposure and limited contact with researchers they had contacted personnel of department of agriculture for various purposes.

The above results in contrast with the findings of Kumar (2004) in his study on tomato cultivators, revealed that 40.83 per cent of the respondents belonged to medium extension contact category followed by 30 per cent and 29.16 per cent belonged to high and low categories of extension contact, in Belgaum district of Karnataka state respectively. The findings were in line with the findings of Ramanna et al., (2000) and Dhamodaran and Vasanthakumar (2001).

\section{Extension contact}

It was evident from the results that majority of gram cultivators had medium to high extension participation. Among different categories of gram cultivators majority of small gram cultivators had low extension participation and medium gram cultivators had high and medium extension participation and no variation was found among big category gram cultivators. The reason for this could be identified that, many extension programmes were in these areas on gram as it is cultivated extensively; hence more participation of gram cultivators was found in these programmes to improve the productivity. However, small gram cultivators had less participation due to limitation of time. The findings were inconformity with Yawalkar et al., (1991) reported that 52.38 per cent of orange cultivators appeared in medium category, followed by 26.19 per cent and 21.43 per cent in low and high extension participation category respectively. The results were in agreement with the findings of Srinivas Reddy (1995) and Angadi (1999).

\section{Achievement motivation}

It was evident from table 1 that nearly one third of the gram cultivators belonged to each of the low, medium and high achievement motivation categories. Among three categories of gram cultivators 50 per cent of big gram cultivators possessed low achievement motivation and nearly equal percentage of medium and small gram cultivators belonged to medium to high level of achievement motivation. In case of big cultivators 35 per cent had high level of achievement motivation.

\section{Psychological attributes}

\section{Scientific orientation}

The data in table 1 indicated that majority of gram cultivators were found in medium level of scientific orientation. Small and medium gram cultivators belonged to medium scientific orientation and in case of big gram cultivators not much variation was found.

Gram was introduced and popularized commercially in Hamirpur during recent past, which attracted many farmers due to higher returns, at the same time it demanded scientific approach in cultivation, hence only those who had scientific orientation might have taken up gram cultivation.

Another reason might be that most of the gram cultivators were interested in intensive cultivation of gram through adopting scientific methods. The results were in contrast with the findings of Sarvanakumar (1996) who found that majority $(70 \%)$ of the mango cultivators of Dharampuri district were 
in the medium scientific orientation category followed by low (15.83\%) and high (14.17\%) category. The findings were in line with the findings of Birajdar (1999).

\section{Achievement motivation}

It was evident from table 1 that nearly one third of the gram cultivators belonged to each of the low, medium and high achievement motivation categories. Among three categories of gram cultivators 50 per cent of big gram cultivators possessed low achievement motivation and nearly equal percentage of medium and small gram cultivators belonged to medium to high level of achievement motivation. In case of big cultivators 35 per cent had high level of achievement motivation.

Achievement motivation is the important determinant of excellence or perfection. Gram cultivators' medium to high level of achievement motivation was due to their higher level of management orientation and aspiration to maximize income. In case of big gram cultivators even though with high education, and social status half of them had low achievement motivation and little more than one third had high achievement motivation which might be due to their large holdings and higher involvement in gram management.

Table.1(a) Personal attributes of gram cultivator

\begin{tabular}{|c|c|c|c|c|c|c|c|c|}
\hline \multirow[t]{2}{*}{ S.No. } & \multirow[t]{2}{*}{ Variables/category } & \multirow[t]{2}{*}{ Category } & \multicolumn{2}{|c|}{ Small } & \multicolumn{2}{|c|}{ Medium } & \multicolumn{2}{|l|}{ Big } \\
\hline & & & No. & $\%$ & No. & $\%$ & No. & $\%$ \\
\hline A. & Personal attributes & & & & & & & \\
\hline \multirow[t]{3}{*}{1} & Age & Young age & 0 & .0 & 3 & 3.9 & 0 & .0 \\
\hline & & Middle age & 2 & 66.7 & 29 & 38.2 & 7 & 33.3 \\
\hline & & Old age & 1 & 33.3 & 44 & 57.9 & 14 & 66.7 \\
\hline \multirow[t]{4}{*}{2} & Education & & & & & & & \\
\hline & & Low & 0 & .0 & 6 & 7.9 & 1 & 4.8 \\
\hline & & Medium & 2 & 66.7 & 58 & 76.3 & 19 & 90.5 \\
\hline & & High & 1 & 33.3 & 12 & 15.8 & 1 & 4.8 \\
\hline \multirow[t]{4}{*}{3} & Land holding & & & & & & & \\
\hline & & Low & 1 & 33.3 & 11 & 14.5 & 5 & 23.8 \\
\hline & & Medium & 1 & 33.3 & 57 & 75 & 12 & 57.1 \\
\hline & & High & 1 & 33.3 & 8 & 10.5 & 4 & 19 \\
\hline \multirow[t]{4}{*}{4} & Annual income & & & & & & & \\
\hline & & Low & 0 & .0 & 13 & 17.1 & 2 & 9.5 \\
\hline & & Medium & 2 & 66.7 & 48 & 63.2 & 17 & 81 \\
\hline & & High & 1 & 33.3 & 15 & 9.5 & 2 & 9.5 \\
\hline \multirow[t]{3}{*}{5} & Farming experience & Low & 1 & 33.3 & 45 & 59.2 & 12 & 57.1 \\
\hline & & Medium & 2 & 66.7 & 31 & 40.8 & 9 & 42.9 \\
\hline & & High & 0.0 & 0 & 0 & .0 & 0 & .0 \\
\hline
\end{tabular}


Table.1(b) Communication attributes of gram cultivators

\begin{tabular}{|c|c|c|c|c|c|c|c|c|}
\hline \multirow[t]{2}{*}{ S.No. } & \multirow[t]{2}{*}{ Variables/category } & \multirow[t]{2}{*}{ Category } & \multicolumn{2}{|c|}{ Small } & \multicolumn{2}{|c|}{ Medium } & \multicolumn{2}{|l|}{ Big } \\
\hline & & & No. & $\%$ & No. & $\%$ & No. & $\%$ \\
\hline B. & \multicolumn{8}{|c|}{ Communication attributes } \\
\hline \multirow[t]{4}{*}{6} & $\begin{array}{l}\text { Mass media } \\
\text { participation }\end{array}$ & & & & & & & \\
\hline & & Low & 1 & 33.3 & 11 & 14.5 & 5 & 23.8 \\
\hline & & Medium & 1 & 33.3 & 57 & 75 & 12 & 57.1 \\
\hline & & High & 1 & 33.3 & 8 & 10.5 & 4 & 19 \\
\hline \multirow[t]{4}{*}{7} & $\begin{array}{l}\text { Organizational } \\
\text { participation }\end{array}$ & & & & & & & \\
\hline & & Low & 1 & 33.3 & 45 & 59.2 & 12 & 57.1 \\
\hline & & Medium & 2 & 66.7 & 31 & 40.8 & 9 & 42.9 \\
\hline & & High & 0.0 & 0 & 0 & .0 & 0 & .0 \\
\hline \multirow[t]{4}{*}{8} & Extension contact & & & & & & & \\
\hline & & Low & 0 & .0 & 13 & 17.1 & 2 & 9.5 \\
\hline & & Medium & 2 & 66.7 & 48 & 63.2 & 17 & 81 \\
\hline & & High & 1 & 33.3 & 15 & 9.5 & 2 & 9.5 \\
\hline \multirow[t]{4}{*}{9} & $\begin{array}{l}\text { Extension } \\
\text { participation }\end{array}$ & & & & & & & \\
\hline & & Low & 0 & .0 & 15 & 19.7 & 5 & 23.8 \\
\hline & & Medium & 1 & 33.3 & 45 & 59.2 & 10 & 47.6 \\
\hline & & High & 0 & .0 & 22 & 28.9 & 3 & 14.3 \\
\hline
\end{tabular}

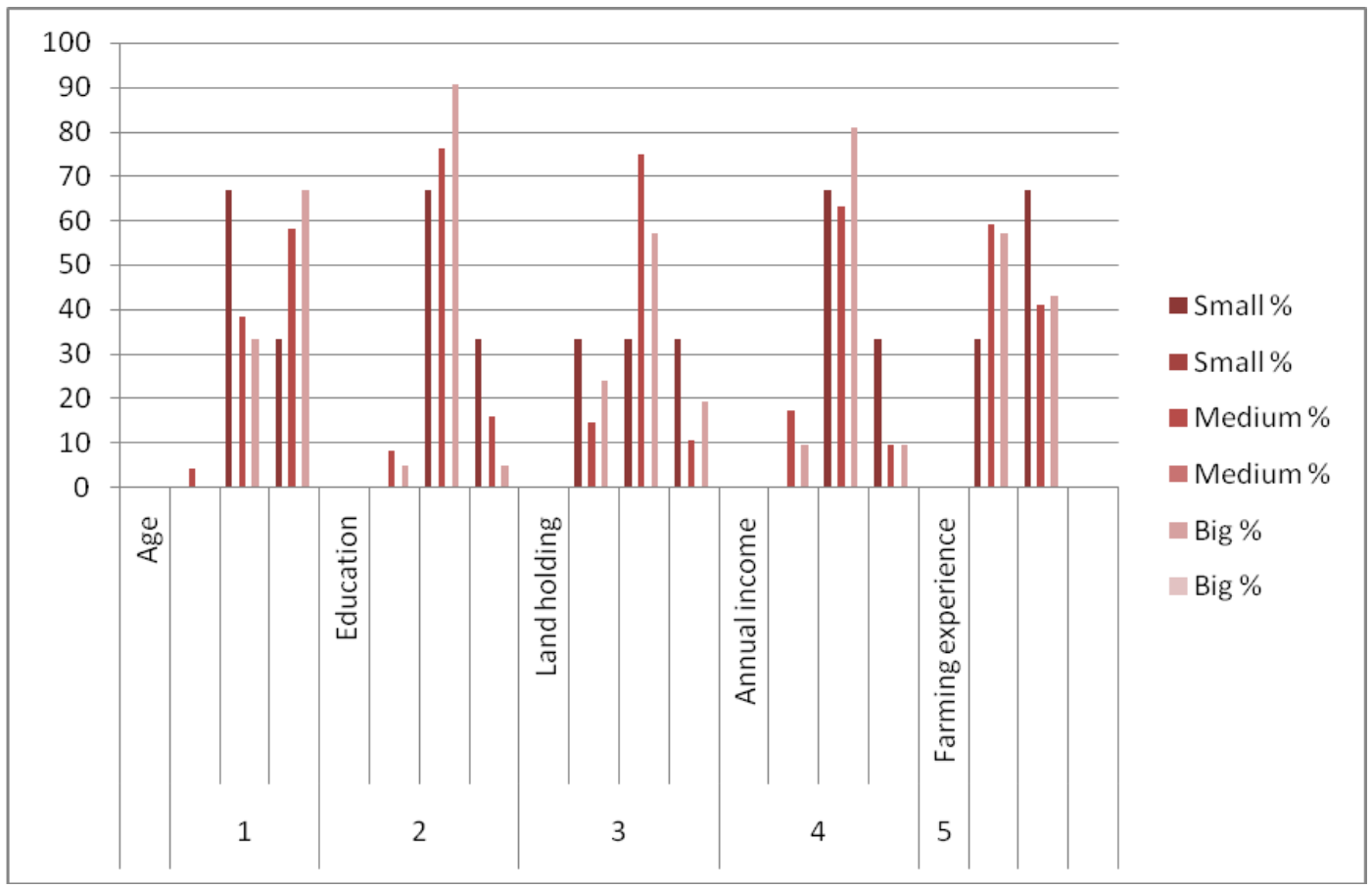

Figure.1(a) Personal attributes of gram cultivator 


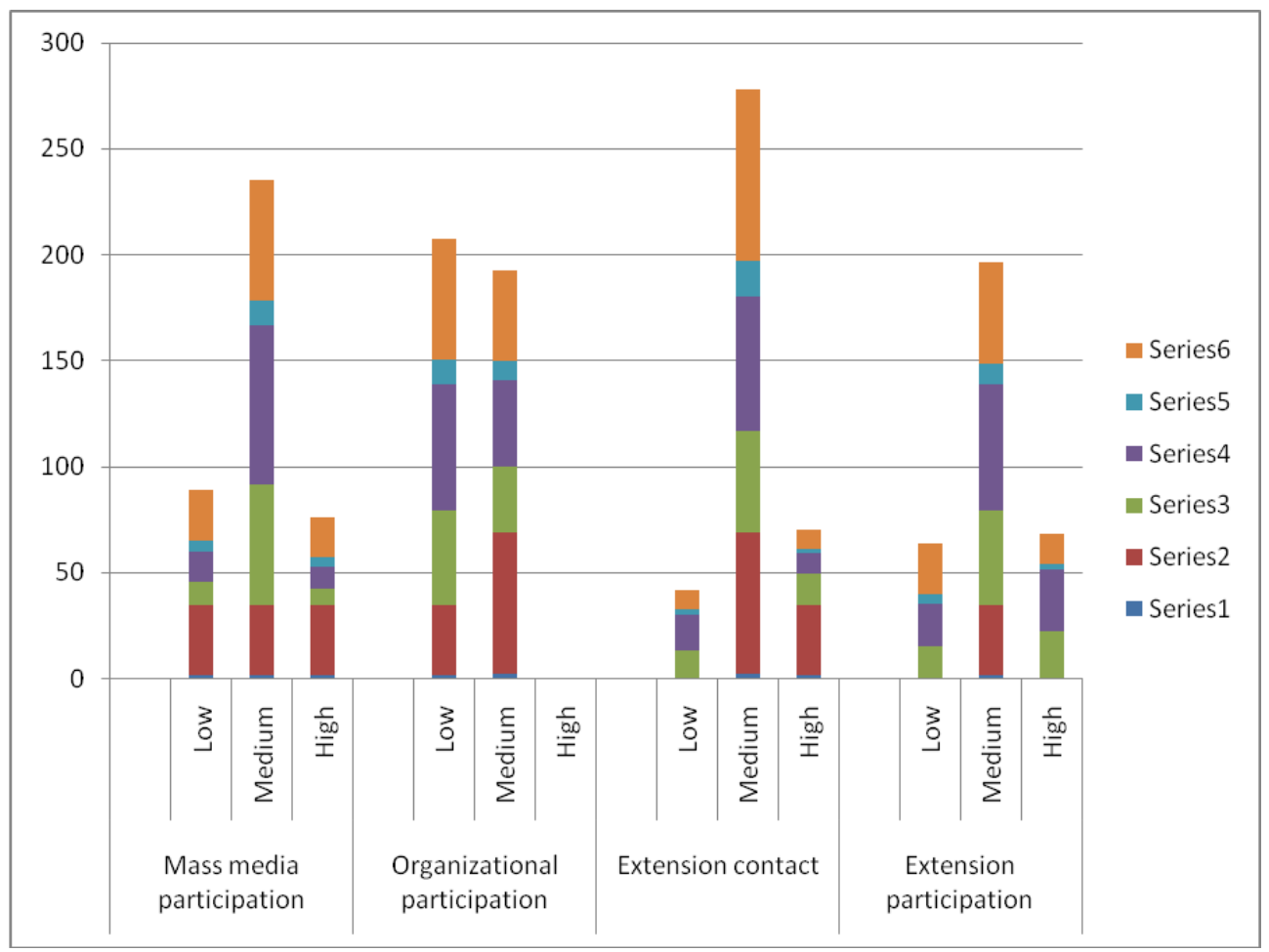

Figure.1(b) Profile chart of gram cultivator of Communication attributes

Gram (Cicer arietinum L.) is an important commercial pulse crop of India, which contributes to the maximum share of export of GRAM and food grain from India to Europe and other parts of the world. The world production of the gram is presently 5,486,235 mts out of which India accounts for 1.2 million $\mathrm{mt}$ of grams making a share of 1.83 per cent of the total GRAM production in the country. Historically, gram is grown mostly for dal making world over. In India, on the country a remarkable success has been achieved in table gram production and yield levels of grams are among the highest in the world.

The study was conducted in Hamirpur districts of Uttar Pradesh State during 2014. This districts were selected purposively, since these district have larger area under grams. Further, Maudaha and Baruwa talluk from Hamirpur district were selected based on the criterion of highest area under gram. Thereafter, four villages having the highest area under grams were selected from each of the taluk in consultation with the respective senior Assistant Director of agriculture. From each of the selected villages, 25 gram cultivators who had at least three year old farm and having minimum of one acre gram farm were selected randomly in consultation with the respective senior Assistant Director of agriculture of these two taluks. Hundred farmers constituted the sample of the study.

Nearly $(66 \%)$ percentage of gram cultivators belonged to middle age and (33.3\%) percentage of gram cultivators belonged to old age category. Majority of gram cultivators were in medium educational level in general and same trend was found in all the three categories. The average land holdings of small, medium and big gram cultivators were 21,31 , and more than 58 acres, respectively. The land holdings of gram cultivators ranged between 15 - 113 acres. The average income of small gram holders is about Rs.1.00 lakh, while large land holders it is around Rs.5.00 
lakhs. Majority had medium farming experience and equal per cent of gram cultivators had low and high gram farming experience. Majority (51\%) had low level of mass media participation and 39 per cent had medium and only 10 per cent had high level of mass media participation. 46.50 per cent of gram cultivators followed by high and medium level of organizational participation almost equal per cent of farmers belonged to high $(36.00 \%)$ and low $(35.00 \%)$ level of extension contact while 29 per cent to medium level of extension contact.

Thirty-nine percentages of farmers had high extension participation followed by medium $(36 \%)$ and low $(24.50 \%)$ extension participation and 44.50 of gram cultivators were found in medium level of scientific orientation. 50 per cent of big gram cultivators possessed low achievement motivation and nearly equal percentage of medium and small gram cultivators belonged to medium to high level of achievement motivation. In case of big cultivators 35 per cent had high level of achievement motivation.

\section{References}

Ajaykumar, P., 1989, A study on adoption behavior and information consultancy pattern of grape cultivators in Rangareddy District of Andhra Pradesh. M.Sc.(Agri) Thesis, Uni. Agric. Sci, Bangalore.

Angadi, S.C., 1999, Study on knowledge, adoption and marking pattern of pomegranate cultivators in Bagalkot district. M.Sc.(Agri) Thesis, Uni. Agric. Sci, Bangalore.

Anonymous, 1976. Report of the National commission on Agriculture. Government of India, Ministry of Agriculture and Irrigation, New Delhi, part XI.
Birjadar Somashekhar, R., 1999, A study on knowledge and adoptionbehaviour of grape growing members frames of Maharashtra Rajya Draksha Bagayatdar Sangh,Solapur. M.Sc. (Agri.) Thesis, Univ. Agric. Sci., Dharwad.

Chandran, B., 1997, A study on knowledge and adoption of frames cultivating tapioca in Ernakulam District of Kerala state. M.Sc. (Agri) Thesis, Univ. Agric. Sci.,Dharwad.

Dhamodaran, T. and Vasanthakumar, J., 2001, relationship between selected characteristics of registered sugarcane cultivators and their extent of adoption of improved sugarcane cultivation practices. J.Extn.Edu., 12(2) : 3138 3143

Govinda Gowda, V., 2002, A study on sustainable grape cultivation practices adopted by Bangalore blue and Thompson seedless cultivators in Bijapur and Bangalore rural districts in Karnataka. Ph.D. Thesis, Uni.Agric.Sci., Bangalore.

Kumbar, S.V., 1993, A study on adoption behavior and consultancy pattern of grape cultivators of Bijapur district in Karnataka State. M.Sc.(Agri.) Thesis, Uni.Agric.Sci., Bangalore.

Meeran, N. and Prince Jayaseelan, M.J., 1999, M.J., 1999, Socio-economic and socio-psychological profile of shrimp farmers. J.Extn.Edu, 10(2) : 2445 2448.

Ramanna, K. N., Chandrakandan, K. and Karthikeyan, C., 2000, Motivation factors and constraints of hybrid sunflower seed cultivators. J.Extn.Edu., 11(3) : 2840 - 2844.

Reddy, P., 1995, Extension system interaction with research and client system - An intersystem analysis. J.Extn.Edu., 12 : 36-42.

Saravanakumar, R., 1996, A study on management of mango gardens by 
farmers in Krihnagiri Taluk of Dharmapuri district, Tamil Nadu. M.Sc.(Agri.) Thesis, Uni.Agric.Sci., Dharwad.

Sashidhara, K. K., 2003, A study on socioeconomic profile of drip irrigation farmers in shimoga and Davanagere districts of Karnataka. M.Sc.(Agri.) Thesis, Uni.Agric.Sci., Dharwad.

Srinivas Reddy, M. V., 195, A study on knowledge and adoption of recommended mango cultivation practices among farmers of kolar district. M.Sc.(Agri.) Thesis,
Uni.Agric.Sci., Bangalore.

Sunil Kumar, G. M., 2004, A study on farmers knowledge and adoption of production and post-harvest technology in toamato crop of Belgum district in Karnataka. M.Sc.(Agri.) Thesis, Uni.Agric.Sci., Dharwad.

Yawalkar, P.B., Nikhade, P.M. and Bhople, R.S., 1991, correlates of adoption of plant protection recommendations of kolsi by orange cultivators - A path analysis. Mah.Jour.Extn.Edu., 10 : 216220.

\section{How to cite this article:}

Vikas Bajpai and Anindita Saha. 2020. Personal, Psychological Situational and Communicational Profile of the Gram Cultivators in Hamirpur District of Uttar-Pradesh, India. Int.J.Curr.Microbiol.App.Sci. 9(03): 2265-2277. doi: https://doi.org/10.20546/ijcmas.2020.903.257 